\title{
Research Paper: Study of Traffic Accident Cases Based on Visum et Repertum in RSUP Dr. Soeradji Tirtonegoro Klaten Hospital During 2014-2016
}

\author{
Patria Putrapratama $^{1^{*}}$, Idha Arfianti Wiraagni², Martiana Suciningtyas Tri Artanti ${ }^{2}$
}

1. Department of Medicine, Faculty of Medicine, Gadjah Mada University, Yogyakarta, Indonesia.

2. Department of Science of Forensic Medicine \& Medikolegal, Faculty of Medicine, Gadjah Mada University, Yogyakarta, Indonesia.

\begin{tabular}{|c|c|}
\hline $\begin{array}{l}\text { Use your device to scan } \\
\text { and read the article online }\end{array}$ & ditation: Putrapratama P, Arfianti Wiraagni I, Suciningtyas Tri Artanti M. Study of Traffic Accident Cases Based on Visum et \\
\hline 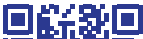 & Repertum in RSUP Dr. Soeradji Tirtonegoro Klaten Hospital During 2014-2016. International Journal of Medical Toxicology \& \\
\hline indsing & Forensic Medicine. 2017; 7(3):171-176. https://doi.org/10.18869/nirp.ijmtfm.7.3.171 \\
\hline 口ifting & doi ${ }^{\circ}$ : https://doi.org/10.18869/nirp.ijmtfm.7.3.171 \\
\hline
\end{tabular}

Article info:

Received: 15 Dec. 2016

Accepted: 23 Mar. 2017

\section{Keywords:}

Traffic accident, Visum et repertum, Klaten District

\section{A B STRACT}

Background: Traffic accident is an unpredictable event which may harm people and damage properties and environment. In recent years, the number of traffic accidents has increased in Indonesia.

Methods: This study is an observational and descriptive study with cross-sectional design. This research was conducted by observing the data based on Visum et Repertum.

Results: Men are more involved in both cases, i.e. $65.1 \%$ in live cases and $73.9 \%$ in death cases. In live cases the most frequent age range belonged to 41-60 years, while in death cases, the dominant age range was between 22 and 40 years. Head injury had the highest reported injury in live cases $(60.5 \%)$ and death cases $(82.6 \%)$. In live cases, the highest number of victims were worker/maid (34.9\%), while in death cases they were mostly private employees. The most frequent time of the accident in live cases was between 12.01 and $1800 \mathrm{WIB}$ (Western Indonesian Time) and death cases between 18.01 and 24.00 WIB.

Conclusion: Most traffic accident victims in both cases were male. Victims' age of live cases was mostly in the range of 41-60 years, while in death case was 22-40 years. Head injury was the most common injury in both cases. Most victims in live cases were worker/maid and private employees in death cases. Traffic accident often occurred between 12.01 and 18.00 WIB in live cases and between 18.01 and 24.00 WIB in death cases.

\section{Introduction}

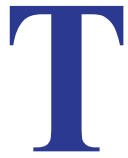

raffic accidents cause more than 1.2 million people death and 20-50 million people injured worldwide [1]. In Indonesia, traffic accidents have increased $11.2 \%$ per year with as many as 256199 injuries and death during 2009-2013 [2] that puts Indonesia in the fifth highest rank in traffic accidents in the world [3]. Based on data reported by Klaten Police Office in 2015 [4], traffic accidents has increased from 2010 to 2014, with the total injuries and death as much as 3733 people.

General Directorate of Land Relations Indonesia defines a traffic accident as an unpredictable event which

* Corresponding Author:

Patria Putrapratama, $M$

Address: Department of Medicine, Faculty of Medicine, Gadjah Mada University, Yogyakarta, Indonesia.

Tel: +62 (858) 68750270

E-mail: ipatpatria@gmail.com 
has multi-factorial causes and it is always preceded by a situation in which one or more road users has or have failed to overcome their environment. Based on UU No. 22 of 2009, traffic accident casualties are categorized into death victims, seriously injured, and slightly injured. In traffic accidents, there are parties who should be responsible for the occurrence of the incident and the party who caused the traffic accident (perpetrator). In the criminal procedure law, the determination of right or wrong doer requires at least two valid evidence and the judge's conviction. Based on article 184 KUHP, the legal evidence includes witness statement, expert statement, letters, instructions, and the testimony of the defendant. In the case of traffic accident, expert testimony is a letter from the doctor about the results of the examination performed on survivors who were injured or the death victims, that is referred to as a Visum et Repertum (Medical report or autopsy report) [5].

As outlined above, the researchers wanted to expose a description of traffic accident cases based on Visum et Repertum in RSUP Dr. Soeradji Tirtonegoro Klaten Hospital during 2014-2016. Researchers chose RSUP Dr. Soeradji Tirtonegoro Hospital because it is the inception of the Faculty of Medicine Gadjah Mada University before moving to Yogyakarta.

\section{Materials and Methods}

This research is a descriptive observational with crosssectional study design. This research was conducted by observing the data traffic accident cases based on Visum et Repertum on RSUP Dr. Soeradji Tirtionegoro Klaten Hospital from January 2014 to March 2016. In April 2016, data collection performed based on exclusion and inclusion criteria. The data then were put into relevant software for analysis.

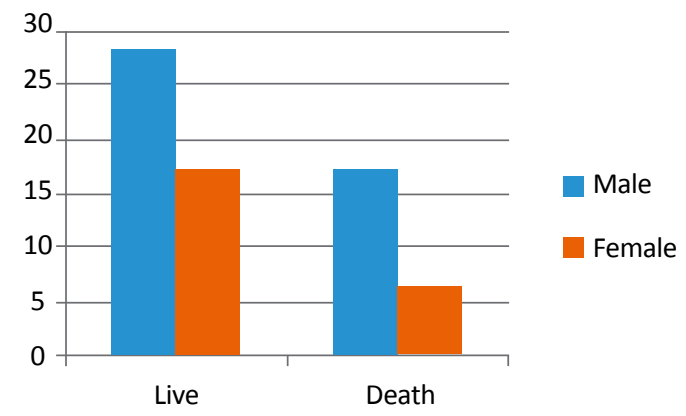

International Journal of
Medical Toxicology \& forensic Medicine

Figure 1. Diagram on the number of victims of traffic accident by the gender
The subjects of this study were live or death victims in traffic accident who requested a Visum et Repertum by the investigators during 2014 to 2016 and fulfilled the inclusion and exclusion criteria. The inclusion criteria were any live and death victims of traffic accident who sought Visum et Repertum at RSUP Dr. Soeradji Tirtionegoro Klaten Hospital, from January 2014 until March 2016. The exclusion criteria were live and death victims of traffic accident who requested Visum et Repertum by the investigator but has incomplete document due to missing of the Letter of Request for the Visum.

\section{Results}

From January 2014 to March 2016, there were 43 live and 23 death victims of traffic accidents. There were $28(65.1 \%)$ male victims and $15(34.9 \%)$ female in live cases, while on death cases we found 17 males and 6(26.1\%) females. Data distribution can be seen in Figure 1.

Victims of live cases aged under 12 years were 2(4.7\%) people; aged 13-17 years, (7.0\%) people; aged 18-21 years, 4(9.3\%) people; aged 22-40 years, $10(23.26 \%)$ people; aged 41-60 years, 14(32.56\%) people; and aged over 60 years, $10(23.26 \%)$ people. In death cases, most victims' ages as $7(30.4 \%$ ) people were $22-40$ years old, followed by over 60 years old with $6(26.1 \%)$ people, 41-60 years old with 5(21.7\%) people, $18-21$ years old with $3(13.0 \%)$ people, and $13-17$ years old with $2(8.7 \%)$ people. The data distribution can be seen in Figure 2.

The number of traffic accident victims based on injury distribution in live cases on head were $26(60.5 \%)$ people, body extremities $16(37.2 \%)$ people, and stomach $1(2.3 \%)$ person. Distribution data can be seen in Table 1. In death cases, the injury distribution dominated in head as many as $19(82.6 \%)$ people, body extremities and neck each with 2(8.7\%) people. Distribution data can be seen in Table 2.

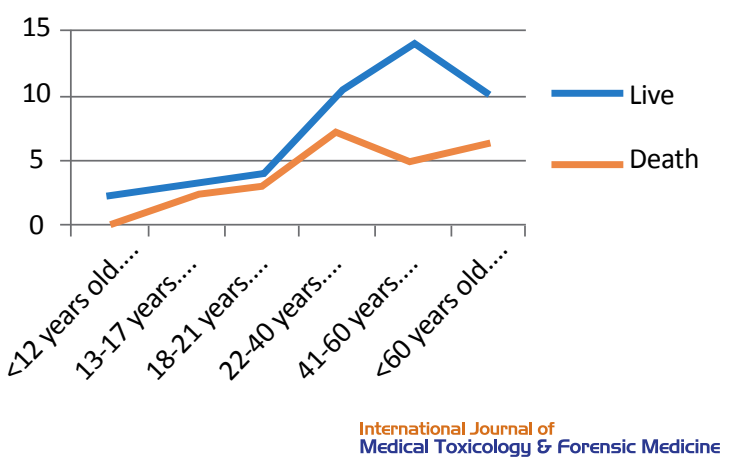

Figure 2. Diagram on the number of victims of traffic accidents with respect to age 
Table 1. Data on the number of live victims of traffic accident based on injury distribution

\begin{tabular}{|c|c|c|}
\hline Injury Distribution & Live Case & Percentage \\
\hline Hymen & 0 & 0 \\
\hline Vagina & 0 & 0 \\
\hline Extremity & 16 & 37.2 \\
\hline Head & 26 & 60.5 \\
\hline Neck & 0 & 0 \\
\hline Chest & 0 & 0 \\
\hline Stomach & 1 & 2.3 \\
\hline No injury & 0 & 0 \\
\hline Total & 43 & 100 \\
\hline
\end{tabular}

With regard to victims' occupation, worker/maid had the highest number in live cases as many as $15(34.9 \%)$ people, followed by private employee with $11(25.6 \%)$ people, civil servant as $6(13.9 \%)$ people, student as many as $7(16.2 \%)$ people, unemployment with $2(4.6 \%)$ people, college student and lecturer as many as $1(2.3 \%)$ person each. In death cases, private employee has the highest number with 10 people (43.5\%), worker/maid as many as 6(26.1\%) people, student and college student as many as $1(4.3 \%)$ person each. Data distribution is shown in Figure 3.

Live traffic accident victims with time event mostly at 12.01-18.00 WIB (West Indonesian Time) were $14(29.8 \%)$ people, followed by $06.01-12.00$ and 18.01-
24.00 WIB with $13(27.7 \%)$ people each, and 00.01-06.00 WIB with $3(6.4 \%)$ people. In death cases, the most accidents happened at 18.01-24.00 WIB with $11(23.4 \%)$ people, 12.01-18.00 WIB with 5(10.6\%) people, 00.01-06.00 WIB with 4(8.5\%) people, and 06.01-12.00 with 3(6.4\%) people. Data distribution can be viewed in Figure 4.

\section{Discussion}

\section{Gender}

Based on the study results, the victims of accidents are predominantly men. This result is smiliar to other studies which state that men are three times more at risk than

Table 2. Data on the number of death victims of traffic accident based on injury distribution

\begin{tabular}{|c|c|c|}
\hline Injury Distribution & Death Case & Percentage \\
\hline Hymen & 0 & 0 \\
\hline Vagina & 0 & 0 \\
\hline Extremity & 2 & 8.7 \\
\hline Head & 19 & 82.6 \\
\hline Neck & 2 & 8.7 \\
\hline Chest & 0 & 0 \\
\hline Stomach & 0 & 0 \\
\hline No injury & 0 & 0 \\
\hline Total & 23 & 100 \\
\hline
\end{tabular}




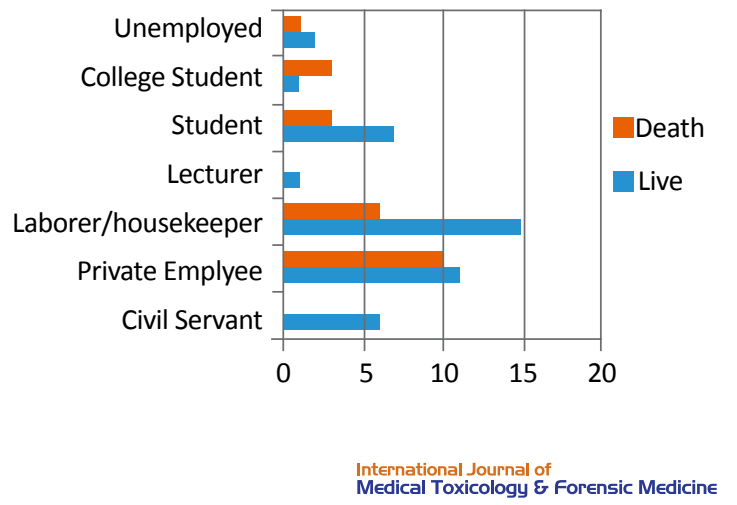

Figure 3. Diagram on the number of victims of traffic accident based on occupation

women [1]. Probably because men often drive with high speed [6]. Other studies attributed higher male victims to their more outside activities compared to females [7].

Age

According to the study results, it can be observed that the victims of traffic accidents in both cases are dominated by those in productive age. According to WHO report, $67 \%$ of traffic accident victims are in productive age [8]. In Indonesia, productive age refers to a period of life when a person seeks a job or already works. It means that productive age group has higher mobility than the other age groups because they often spend their time on the street for working.

\section{Injury distribution}

Based on the study results, the injury caused by the traffic accidents are mostly in the head in both cases. Motorcycle accident give the highest contribute in head injury by traffic accident. This statement is in line with

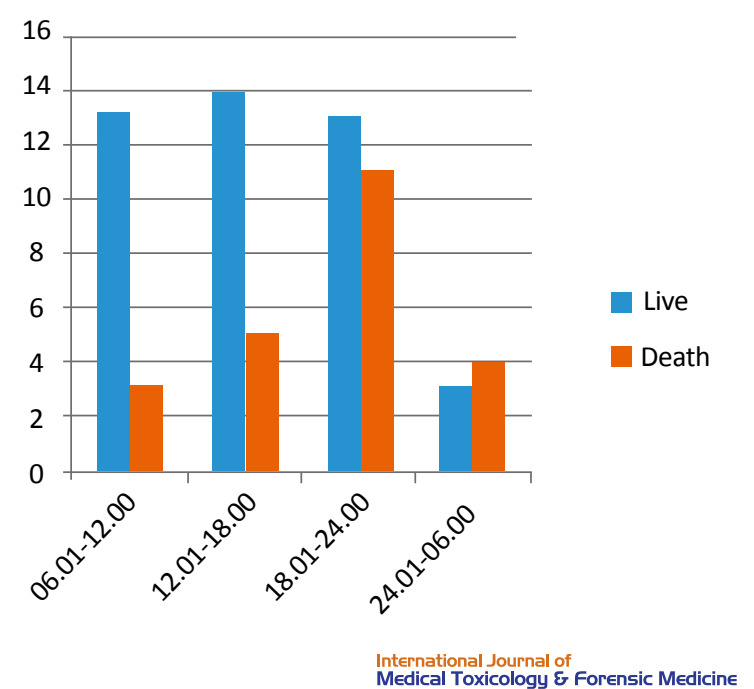

Figure 4. Diagram on the number of victims of traffic accident based on time event the number of motorcycles in Klaten District which reach 359741 and placed in the third place as the most motorcycle number in Central Java, Indonesia [9].

\section{Occupation}

Regarding the victims' ocupations, worker and private employee have the highest number in live cases and death cases, respectively. The high number of worker/maid in traffic accident casualties is probably because this job belongs to low socioeconomic groups [10]. Lower socioeconomic class knows nothing or a little about traffic regulations due to the lack of education on safety driving [11]. The high number of private employees as traffic accident victims is in line with the statement of Klaten Ploice Chied, mentioning that victims of traffic accidents in Klaten are dominated by private employees as many as 403 victims, followed by students as 158 victims, and others as 54 victims [12].

\section{Time of the accident}

Finally, most accident happened between 12.01 and 18.00 WIB in live cases, and between 18.01 and 24.00 WIB in death cases.

\section{Conclusion}

Based on the results of research that was conducted in RSUP. Dr. Soeradji Tirtonegoro Klaten hospital and our discussion, we can conclude that in the case of traffic accident from January 2014 to March 2016: 1) The male victims were higher than female ones in both cases; 2) Victims' ages of traffic accidents are mostly in the range of 41-60 years in live cases and 22-40 years in death cases; 3 ) Injuries were mostly seen in victims' heads in both cases; 4) Most victims in live cases were worker or maid, while private employees in death cases; and 5) Most accidents happened between 12.01 and 18.00 WIB in live cases, whereas between 18.01 and $24.00 \mathrm{WIB}$ in death cases.

\section{Acknowledgements}

This research is part of a thesis (Case Characteristic of Visum et Repertum in RSUP Dr. Soeradji Tirtonegoro Klaten 2014-2016). RSUP Dr. Soeradji Tirtionegoro Klaten Hospital has financially supported this research.

\section{Conflict of Interest}

The authors declared no conflicts of interest. 


\section{References}

[1] Peden M, Scurfield R, Sleet D, Mohan D, Hyder A, Jarawan $\mathrm{E}$, et al. World report on road traffic injury prevention. Geneva: World Health Organization; 2004.

[2] Asmarawati T. [Offenses outside the Indonesian Criminal Code (KUHP) (Indonesian)]. Yogyakarta: Penerbit Deepublish; 2015.

[3] Sondakh S, Siwu JF, Mallo JF. [Visum et Repertum prevalence in live victim of traffic accident cases in emergency room of Prof. Dr. R. D. Kandou Manado Hospital period 2013 (Indonesian)]. Jurnal e-Clinic. 2015; 3(1):606-611.

[4] Klaten Police Department. [Report of traffic accident cases in Klaten District (Indonesian)]. Klaten: Klaten Resort Police Department; 2015.

[5] Ranoemihardja RA. [Medical science of judiciary (Forensic science) (Indonesian)]. Vol. 2. Bandung: Tarsito; 1991.

[6] Angela ZA, Tomuka D, Siwu J. [Wound pattern on traffic accident cases in Emergency Room of Prof. Dr. R. D. Kadou Manado Hospital period 2010-2011 (Indonesian)]. Jurnal eBiomedik (eBM), 2013; 1(1):683.

[7] McGreevy J, Stevens KA, Ekeke Monono M, Etoundi Mballa GA, Kouo Ngamby M, Hyder AA, et al. Road traffic injuries in Yaoundé, Cameroon: A hospital-based pilot surveillance study. Injury. 2014; 45(11):1687-92. doi: 10.1016/j.injury.2014.05.001

[8] World Health Organization. Global status report on road safety 2013: Supporting a decade of action. Geneva: World Health Organization; 2013.

[9] Suprapta. [Number of motors in Klaten Terbesar Ketiga (Indonesian)] [Internet]. 2009 [Cited 2009 March 4]. Available from: https://suprapta22663.wordpress.com/2009/03/04/ jumlah-motor-di-klaten-terbesar-ketiga/

[10] Joly MF, Foggin PM, Barry Pless I. Geographical and socioecological variations of traffic accidents among children. Social Science \& Medicine. 1991; 33(7):765-9. doi: 10.1016/02779536(91)90375-m

[11] Solopos Digital Media. [Klaten accident (Indonesian)] [Internet]. 2014 [Cited 2014 November 28]. Available from: http://www.solopos.com/2014/11/28/kecelakaan-klaten10-bulan-740-kasus-laka-555702

[12] General Directorate of Land Transportation. [Study on the formation of the Land Transport Safety Board (Indonesian)]. Jakarta: General Directorate of Land Transportation; 2006.

[13] Marsaid M, Hidayat M, Ahsan A. [Factors related to the incidence of traffic accidents on motorcyclists in the district police district Malan (Indonesian)]. Jurnal Ilmu Keperawatan. 2013; 1(2):98-112. 
